\title{
Miranda
}

Revue pluridisciplinaire du monde anglophone /

Multidisciplinary peer-reviewed journal on the English-

speaking world

17 | 2018

Paysages et héritages de David Bowie

\section{Autobituary: the Life and/as Death of David Bowie $\&$ the Specters from Mourning}

Jake Cowan

\section{OpenEdition}

\section{Journals}

\section{Electronic version}

URL: http://journals.openedition.org/miranda/13374

DOI: 10.4000/miranda.13374

ISSN: 2108-6559

Publisher

Université Toulouse - Jean Jaurès

\section{Electronic reference}

Jake Cowan, "Autobituary: the Life and/as Death of David Bowie \& the Specters from Mourning"

Miranda [Online], 17 | 2018, Online since 20 September 2018, connection on 16 February 2021. URL http://journals.openedition.org/miranda/13374 ; DOI: https://doi.org/10.4000/miranda.13374

This text was automatically generated on 16 February 2021.

\section{cc) (i) () $\Theta$}

Miranda is licensed under a Creative Commons Attribution-NonCommercial-NoDerivatives 4.0 International License. 


\title{
Autobituary: the Life and/as Death of David Bowie \& the Specters from Mourning
}

\author{
Jake Cowan
}

\begin{abstract}
La mort m'attend dans un grand lit
Tendu aux toiles de l'oubli

Pour mieux fermer le temps qui passé

- Jacques Brel, « La Mort »
\end{abstract}

1 For all his otherworldly strangeness and space-aged shimmer, the co(s)mic grandeur and alien figure(s) with which he was identified, there was nothing more constant in David Bowie's half-century of song than death, that most and least familiar of subjects. From "Please Mr. Gravedigger," the theatrical closing number on his 1967 self-titled debut album, to virtually every track on his final record nearly 50 years later, the protean musician mused perpetually on all matters of mortality: the loss of loved ones ("Jump They Say," about his brother's suicide), the apocalyptic end of the world ("Five Years"), his own impending passing. In between, Bowie donned and dusked various personas, restlessly laying to rest the many faces he wore-the Goblin King buried the Blue Clown, who had buried the Thin White Duke, who had buried the Man Who Fell to Earth, and so on, one after another, ashes to ashes, each having to perish in order for the performer to move on: "this ain't rock 'n' roll," he wails just before the titular track of Diamond Dogs, "this is genocide."

2 Yet in a discography haunted by the ghosts of so many disc-guises, in a career constantly on the verge of death-"Space Oddity" was just a loony novelty, glam a passing phase-Bowie was likewise no stranger to resurrection in the broadest sense, having constantly and brashly reinvented his sound and look from album to album, from funk to funky shedding genres and identities with serpentine savvy: he was always already a dead man walking, falling up through the years. In other words, the common chameleon has always been the wrong animal metaphor for the warm impermanence of Bowie's changes: unlike the lizard's motley mutations, he never sought to camouflage himself, his aesthetic evolution instead being more akin to a 
bird's iridescent molting, wherein season after season the singer shook his tail feather(s loose) in a compulsion to renew that was simultaneously a death drive. Said otherwise, Bowie's characteristic creative metempsychosis at the same time necessitated his interring earlier selves, the Freudian Wiederholungszwang and Todestriebe paradoxically naming a unitary motion in two directions at once, both a pull back to the womb (birth being the essential state of repetition and renewal) and a push toward the tomb (death becoming the buried ground prerequisite to life). Following on the rock 'n' roll suicide of Ziggy Stardust, interred at the Hammersmith Odeon in July of 1973, came Aladdin Sane, laid waste eventually by "the sniper in the brain," the "regurgitating drain" of time's all-consuming vamp, "incestuous and vain." And in his dying, a lad insane begat Halloween Jack, whose death begat Thomas Jerome Newtonwho we will see born again 40 years later, after decades of further self-reimaginings and sonic transformations, frequently unnamed, that cyclically regenerated Bowie's iconic status for new generations. Such changes were the lifeblood of Bowie's artistry, albeit a lifeblood of a darkly morbid humor, an impulse of mourning that structures the singer's relationship to his past life, his afterlife, and the quasi-present living and dying, the rising and falling of his alter egos.

3 In the brief time that I will be granted your attention and given your hands, I would like to address these strange specters that haunt Bowie's final output: both the ghost of his much lauded, very loud past, and the ghost that will have been of his coming passing, the shadow of his death stretching out before him. Following the hauntological work of Jacques Derrida and a few of his followers, I want to consider the ways in which the late David Bowie came to haunt the late David Bowie-that is to say, how the performer's mortality became the condition of possibility for his last albums. In tracing these ghostly traces, I hope to show how these records function as more than records, providing an alternative form of self-writing (and autodeictic mourning) beyond the narrative closure attempted by ordinary autobiography, a form of spectral rhetoric that I will outline as autobituary. Through this practice of haunted (de)composition on his final album, Blackstar, I propose that Bowie offers one response to Derrida's call for a new "scholar"-albeit in a musical fashion, less a scholar than a holler-that "would finally be capable, beyond the opposition between presence and non-presence, actuality and inactuality, life and non-life, of thinking the possibility of the specter, the specter as possibility" (Specters 12). In this, I hope to show how Blackstar answers, with quarter notes in lieu of footnotes, Michelle Ballif's invitation "to retheorize rhetorical practices while acknowledging the address, the addressor, and the addressee as being essentially haunted," in a way that "renders rhetoric an ethical rather than an epistemological enterprise" ("Regarding" 466, emphasis in the original). By attuning his tunes to his as-of-yet-undetermined termination, by giving voice to his giving up the ghost, and by writing (towards) his own death in the form of an autobituary, I want to suggest that Bowie foregoes the usual autobiographical attempts to master one's own story-there is ultimately no mooring mortality-and instead provides through his work a means of assisting and joining his listeners in their work of mourning.

But before we get to that-his and our-end, we need to circle back, to the beginning of the end: for the width of an artless decade, the last many thought we would hear from Bowie was 2003's Reality. While touring for the album in Germany the following June, quite literally "struggling for reality," the singer suffered a heart attack on stage, and the resultant recuperation shifted imperceptibly, presumably, into quiet retirement. When, in the spring of 2013, he suddenly broke that silence with the release of the aptly 
titled The Next Day and its first single, "Where Are We Now?"-the question on so many minds-the album was welcomed as an unexpected resurrection, as all resurrections are: Bowie has returned from his grave absence to tell us there is something after Reality. "Here I am, not quite dying," he growls ferociously on the opening track, "my body left to rot in a hollow tree"-seemingly buried alive, Bowie's grim lyrics affirm the simultaneous nonpresence of death hanging in the air ("its branches throwing shadows on the gallows for me") and life's lingering: to survive, to be here at all, is to not quite die, not yet at least.

5 The theme of a preoriginary relationship of mourning between life and/as death looms throughout the album, weaving together tracks that stylistically sweep across the breadth of Bowie's oeuvre, "words that," as Ryan Dombal noted in his Pitchfork review of the album, "don't glorify death as much as they detail its cruel inevitability throughout history [...] describing nothing less than eternal brutal violence" through both a world history that the icon has helped to shape and personal his-story in the shape of sharps and flats. On the former scale, Bowie sings of Cold War assassins ("You Feel So Lonely You Could Die") and hot-blooded wars ("How Does the Grass Grow?"), of medieval mobs ("The Next Day") and modern school shootings ("Valentine's Day"), all the while wheeling through so many of his past styles like, in the words of Neil McCormick's review for The Daily Telegraph, a "musically jagged, electric bolt through his own mythos." Here comes the Thin White Duke, strutting for a last time to the funky funk of "Dirty Boys" and "Boss of Me," followed soon by Jareth, having traded his bulging labyrinth for "dancing out in space." Most ethereal, however, is the drumbeat decrescendo that closes out "You Feel So Lonely You Could Die," uncannily echoing the same pattern that opened "Five Years" some 40 years before. With this, the track allusively equates the commercial breakthroughs of both Elvis (the title comes from a line in "Heartbreak Hotel") and Bowie, the king and the duke, between on the one hand the popular birth of rock as figured in a hunka-hunka greaser clad in leather and, on the other, an apocalyptic vision of glam culture's indifferent indulgence, embodied in the glimmering androgyny of one-legged catsuits: “you're a rock 'n' roll suicide."

In the line drawn between the origin of pop stardom and its disillusioned excesses, between the overture of the rock era and its overkill in the aftermath of Altamont, we can see how Bowie also blurs the line we often take as obvious between life and its limits, which ultimately means death. Hence Simon Critchley's claim that "[t] $]$ he basis, the constant, the ground of Bowie's most important work is that the world is screwed, used up, old and done," and that his vision of contemporary culture "is continually dystopian" (59), from the cheap propaganda of "Cygnet Committee" to the war-torn history underlying The Next Day. Moreover, this is more or less in line with what Ballif outlines as "the preoriginary mourning that structures relations" ("Regarding" 467), an "impossible work of mourning [that] haunts the possibility of the address, constituting the ethical relation between the self and the other, the otherness of the self, and the otherness of the other" ("Regarding" 456). Bowie thus comes to perform the paranormal possibilities described in Derrida's hauntology, which aims for the impossible and the irreducible in trying "to speak always of the specter, to speak to the specter, to speak with it, therefore especially to make or to let a spirit speak" (Specters 11). Yet how does a logic of haunting, this séance within any saying, come to be "first of all to everything it makes possible" (Specters 51), so that death can be said to ultimately come prior to 
life, or more precisely, so that life is conditioned and permeated by its limit(s), its end(s), its fatal aim?

7 As is well known, but which bears repeating nonetheless, Derrida builds off of Saussurean linguistics to maintain that all signification belongs to a minimal structure of difference and iterability, wherein no sign or mark, no ontic instance or identification exists within a vacuum, capable of sovereign self-presence, but rather always already relies on a "non-full, non-simple" system of differential relationships in order to become manifest (Margins 11ff.). This structure is such that a sign's inability to coincide with or be fully present to itself, and its concurrent dependence on (difference from and deferral to: différance, in a word) every other sign in a system, is the condition of possibility for any meaning to emerge whatsoever, a capacity for signification that Derrida ascribes to the movement of what he calls a sign's constitutive nonpresent and nonabsent trace. "To be what it is," explains Diane Davis of how this logic functions, "a being must mark itself (off from the other) repeatedly in a gesture of self-reference; repeating itself to gather itself, it must both leave and trace traces, address and respond," span the division and cross the line between presence and absence, writing and erasure. Davis continues: "the trace-the entwinement of the other in the same that makes the 'same' possible-is already the heart of any sign; it's the most basic unit of communication, and it's not simply human," nor is it simply for the living (547). In/ forming any and every sort of signification, then, is a relationship of différance with/ from/to other(s), a structure of traces that requires meaning to revolve around the nonpresent absence of the sign with/from/to itself.

8 The structure of this constitutive disunion interior to a signifier, dividing it from itself and puncturing the appearance of a sign's full presence with its inevitable and necessary absence, is the same as that which underlies Bowie's restless and reflexive changes in persona over the decades: "So I turned myself to face me," he declares in a gesture of self-reference indicative of the trace that already splits the self and allows for a moment of self-consciousness; "but I've never caught a glimpse," he continues, the achievement of full self-presence being strictly impossible. Every sign, any thing with meaning whatsoever, is thus a word on a wing-Derrida flatly rejects the classical axiom scripta manent (Limited 53), so that he might instead agree with Jacques Lacan that "[i]t is scripta which volant" (198)-unfixed, unfolding, unable to stand in its own light as we try to fit it within the larger scheme of things. In his essay "Différance," Derrida demonstrates how signification, and all it entails, arises only by dint of differentiation, by way of what that sign is not, and all the more so since signifying can only occur in passing and is never more than "deferred presence," as the meaning that is voiced (Margins 8), and the entire relational system that that work relies on, cannot be coterminous with a sign's enunciation, the trace at its core being "not a presence but the simulacrum of a presence that dislocates itself, displaces itself, refers itself [...] erasure belong[ing] to its very structure" (Margins 24).

9 A sign can never merely be or fully be what it is or where it is tout court, for a sign can neither step out of time and designate itself hic et nunc, nor step out of line and isolate itself from the chain of others; and in that futility of self-presence, in its reflexive absence and differential prerequisite, each sign ineluctably must "turn and face the strange," as Bowie's work implores, must confront what it is not, which ultimately means the is-not of its own unfamiliar finitude, its own impossibility of possibility, its own death. Furthermore, Derrida proposes that "[t]o be what it is," another, similar 
absence necessarily preoccupies all signification, in that the act must always already "be capable of functioning in the radical absence of every empirically determined receiver in general. And this absence is not a continuous modification of presence, it is a rupture in presence, the 'death' or the possibility of the 'death' of the receiver inscribed in the structure of the mark" (Limited 8). Figured in this way, cradled between scare quotes, "death" conditions iterability, allowing (for) whatever instance of meaning to survive the potential but indispensable absence of both/either the addressor and addressee. As Ballif clarifies in a gloss of this exact passage from Limited Inc, "signification is possible (as iterable) only because of death. Death is the condition of the address" ("Regarding" 459), but in a way that never can achieve absolute absence either, for the trace that marks death, the mark that is the trace of death, is "[a]lways available for reanimation" (Davis 547), a deferred presence that, "like the dead-or more to the point, the (un)dead, like the specter, who haunts" (Ballif, "Regarding" 458) -has the uncanny status of that/who remains. On one hand, the dead are indistinguishable from what Bowie calls those "clutches of sad remains," yet in the sheer fact of their remaining, the dead are nonetheless characterized by what Derrida describes as a constitutive "weave of survival, like death in life or life in death, a weave that does not come along to clothe a more originary existence, a life or a body or a soul," since even these ultimately "live to death as the very inextricability of this weave" (The Beast 132). "Much of Bowie's work circles obsessively around this dilemma," argues Critchley (48), functioning to expose the interwoven traces between life and death, the structure of presence that contains within itself a sign's own absence, "show[ing] that dying is living beyond reason," as Bowie puts it in "Saviour Machine" on his most Nietzschean album, 1970's The Man Who Sold the World.

Insofar as a differential structure of absence and iterability founds all signification, any capacity to communicate or come-to-be whatsoever, then any instance of singularity is constituted through a relationship to an originary other. To put it another way, others and otherness always already materialize through/with/to one another, a condition of response-ability long recognized in Bowie's work, particularly his love songs: "With your kiss my life begins, you're spring to me, all things to me," he confesses to an unnamed other in "Wild is the Wind" from 1976, and again on "Days" nearly three decades later, he continues to avow that "all the days of my life, all the days I owe you." Pushing this logic still further, we understand how the first other that hails us and demands an address is necessarily dead, the other (which might be the self) figured as in part missing, as never wholly present, because the other likewise requires a constituting other (at the very least the former self). "Absence of presence (death)-the always-deferred present," which is to say, an ever-coming death, a death never wholly here-is "what makes signification possible," explains Ballif, and "indeed, the addressthe possibility of the address to/with/from the dead-is what constitutes any addressor or addressee" ("Regarding" 458f.). This does not mean, however, that the rhetorical situation is dead already, only unaware of its condition for the time being, but instead that all signification is at bottom an obituary, structured by a preoriginary mourning for the unavoidable loss and the finitude of the other, the self, and even the address itself: "because of all we've seen, because of all we've said," Bowie sang, "we are the dead." Contrary, then, to "the rhetorical commonplace of living humans speaking to living humans" (Ballif, "Regarding" 459), wherein the dead can tell no tales, and especially not their own, a preoriginary "structure of mourning," as Joan Kirby makes plain, "is that of an ongoing conversation with the dead" (467)-if you will, a dialogue 
among specters announcing their (non)presence, between beings set between the unsettled traces of life and/as death, a rhetorical situation where now the dead speak to the living.

11 This conception of a preoriginary mourning that addresses as inherently past and passed away the other and the self (which can be no more than an other-self, an alter ego) thus stands in contrast to more traditional theorizations of mourning that "consists always in attempting to ontologize remains, to make them present," argues Derrida, "by identifying the bodily remains and by localizing the dead [...] to know who and where, to know whose body it really is and what place it occupies-for it must stay in its place" (Specters 9), buried in the (metaphysical) ground that assures the alive of their life, that those who have left this plane will rest (and leave the living) in peace. According to the usual account, "mourning demands that we revive, relive and then relinquish the memories that tie us to the dead" (Kirby 464), which amounts to "a refusal to submit to transformation-to be reorganised and reconstituted in relation and response to the lost other" (471). Classical Freudian analysis, for example, suggests that successful mourning "demand[s] that all libido shall be withdrawn from its attachments to [a lost loved] object" (244), a letting go of the gone other, whereas Melanie Klein contends conversely "that every advance in the process of mourning results in a deepening in the individual's relations to his [sic] inner objects, in the happiness of regaining them after they were felt to be lost" (144). But either way, the end result is the same: a person's end results in sameness, in their being fixed in time, no longer a being of becoming as in life, an objectification which "effectively obliterate[s] the otherness of the other," says Ballif, "violat[ing] its radical alteritythat which could not be interiorized and still remain other" ("Regarding" 462).

In contrast to this, Derrida develops Nicolas Abraham and Maria Torok's vocabulary of incorporation and introjection to offer a substitute model of mourning more faithful to its preoriginary structure, one that "depathologises mourning and sees it as the opportunity for a continuing engagement with the legacy of the dead who remain within us and yet beyond us, and who look at us with a look that is not ours to do with what we will, but a look that is a call to responsibility" (Kirby 461), to continue the ongoing conversation "to/with/from" our specters (to borrow Ballif's prepositional conjunction). All too briefly: As Derrida explains of these terms, introjection names "the process by which autoerotic cathexes are extended," a process wherein a loved-yet-lost object is taken into the psyche such that "it advances, propagates itself, assimilates, takes over," and "expands the self" ("Fors" xvi). On the contrary, with incorporation "[t]he self mimes introjection" so that the loved-yet-lost object is treated as "a foreign body preserved as foreign" even as it has been assimilated, at one and the same time maintained within the psyche yet rejected, "excluded from a self that thenceforth deals not with the other, but only with itself"("Fors" xvii). In line with Klein's objectrelations, the act of incorporation-which constitutes "a reassuring fantasy for the ego" (132), not a psychical process of reality-testing-is a refusal "to 'swallow' a loss," imaging instead having swallowed "that which has been lost, as if it were some kind of thing" (126), tucking away the objectified loss inside the crypt of the unconscious, making it and the self invulnerable to further changes. Incorporation thus names a "refusal to reclaim as our own the part of ourselves that we placed in what we lost," a "refusal to acknowledge the full import of the loss, a loss that, if recognized as such, would effectively transform us" (127). Alternatively, introjection means "the successful replacement of the object's presence with the self's cognizance of its absence," 
assimilating a loss so as to leave the subject empty enough to fill itself up again with words, with the talking cure (128). Nonetheless, such a dialogic digestion destroys the alterity of the other, transforming the departed into an integral part of the expanded ego, so that no matter how hard we try, how deeply we mourn, how much of the other we attempt to take in and safeguard, the other "can't live within you," as Bowie says on "Within You" from 1986, any more than a self can live without the other.

Derrida points out, however, how even this new paradigm is ultimately as inadequate and entangled as Freud's dualism, since everything about introjection and incorporation "is organized in order that [the dead other] remain a missing person in both cases, having vanished, as other, from the operation, whether it be mourning or melancholy. Departed, nowhere to be found, atopique" ("Fors" xxxviii), the other either is put to death twice through introjection-the loss itself being lost, the other transmuted into the self/same-or, in the fantasy of incorporation, "[t]he very fact of having had a loss would be denied" (Abraham and Torok 129), no death would have occurred at all and the ultimate alterity of the other is rejected. Regardless of what final approach an analyst might land on, Derrida insists ("Fors" xxii) "that the otherness of the other installs within any process of appropriation (even before any opposition between introjecting and incorporating) [...] an undecidable irresolution" that makes mourning as much of an impossibility as death is an impossibility (of possibility), precisely because death and mourning are in the end not at the end, but as Ballif says, are "always already with/in the self in a preoriginary way" ("Regarding" 462). The challenge is therefore not to know how to mourn properly, because we have donned already the gloomy colors of preoriginary mourning since well before the dawn of our first morning, mourned since before the beginning and the burial both. Because we will have never finished mourning, can never hope to bring to an end our responding to the end, can never do away with the passed away, the late other who at the same time is the earliest other. Because the deceased other is irreducibly so, resisting total assimilation or subjective closure, the question thus becomes one of learning how to return to our specters in a way that allows our specters to return, to return to the dead the trace of life that was lost during their ontotheologizing interment. Insofar as the familiar and firm division of life from death is upset by the deconstruction of mourning, we become tasked with, in Bowie's terms, "believing the strangest things, loving the alien," accepting and respecting the foreigner who exists before us and within us, who will succeed us and already exceeds us, "watching them come and go" across the "tomorrows and the yesterdays" without needing to restrain or repress the dead. Insofar as a trace of the absent is always already with/in the self, constitutive of interiority and self-relation as such, we are called to address our specters not through even greater internalization, but through "a thinking externalising memory that gives us over to writing and thought in a future-oriented engagement with the dead" (Kirby 466f.).

This, I submit, is the work of mourning that David Bowie's final creative burst performs, which seeks not to bury what haunts him or to place what looms before him beneath the (metaphysical and self-certain) ground. Instead, by remaining open to the spectral structure of signification and attentive to the traces of his past and future alike, Bowie's late work mourns with and not merely for the other by re-membering the trace of community that constitutes the self, reckoning with the inassimilable alterity that makes and breaks the self, a little bit of the beyond deep within the self. Thus when Bowie roars that he is "not quite dying" on The Next Day-even as he will be dying 
the day after that-the singer is not denying his mortal condition, nor raging against the dying of the light. Like the rest of the album, rather, the lyric suggests the "undecidable irresolution" that marks the difference between life and/as death, acknowledging the inevitable ("dying") that nonetheless remains only an ineffable ("not quite") trace. By the same token, Rick Moody has observed that the Derridean trace, by Bowie's own admission, "seems to be the art of" The Next Day, "as if a residuum is all that we can speak of [...] and in Bowie's songs, the meanings exist like a wash of references, these songs are about a flux of meaning, a collision of meanings, or: they are composed of traces." Rotating through so much of his artistic development, visiting all the old haunts from station to station or from Ibiza to the Norfolk Broads, recovering so many passed personae without resorting to cover songs or covering over the blemishes with still more makeup, Bowie nevertheless avoids transforming his musical historiography into a narrative hagiography or a hermeneutical game of decryption, refuses to tell his story straight, as if the future was set and the past settled. By placing his specter(s) over six strings rather than six feet under, by sublimating history into a future-oriented work of creative engagement, Bowie can be said to (de)compose, as Ballif might describe it, "with/in a haunted, uncanny sense of the past, present, and the future-indeed, with a sense that linear, historical time is 'out of joint,' and that the borders between the past and the future remain-not only permeable, but -impossible" (Theorizing 141).

The autobiographical kaleidoscope found on The Next Day was echoed by the nearly simultaneous opening of David Bowie Is..., an archival retrospective staged at the Victoria and Albert Museum in London; moreover, instead of touring with a live band, the show visited museums the world over, placing the accouterment of his artistry on display "in the conspicuous absence of the being who inhabited and/or created them" (Murray). Nonetheless, that absence is telling in that it hints at the same preoriginary structure of mourning, the same ghostly ambiguity between life and/as death that propels The Next Day: being neither wholly there nor wholly absent, by way of his costumes and instruments, Bowie becomes a trace to his traces and a specter for the retrospective's spectators, thereby morphing museums into mausoleums. In fact, we can see this nonpresent, nonabsent trace operating in the exhibition's title, plastered in towering capitals against a electric orange background at the entrance to the show, the official ellipsis replaced by a mad lib-like line of underscores: DAVID BOWIE IS ___.. On the lightening-bolted face of things, the exhibit asks visitors to fill in the blank with some associated character(istic)-"Bowie is Major Tom" or "Bowie is low," phrases scrawled on walls around the show-underscoring his multitudinous and overdetermined catalogue, while on the other hand implying that something about the performer remains fundamentally undecided, inviting interpretation, and suggesting that Bowie is (who you want him to be, someone different to/for each fan).

Yet can we not also read the title in a more literal manner, as signifying graphically that Bowie is that blank space, nothing more than that haunted void through which the chain of predicates and identifications circulate, that at one and the same time he is and/as he is null, lacking positive determination? In his wonderful monograph on the singer-published concurrently with The Next Day, and so necessarily unable to attend to the mourning of Blackstar-Critchley has suggested this is the source of Bowie's "weird and rare" position in popular music, the genius of an artist who has "almost ascetically, almost eremitically, disciplined himself into becoming a nothing, a mobile and massively creative nothing that could assume new faces, generate new illusions, and 
create new forms" (89). As the title of his archival exhibition intimates, the performer's work is constituted not only by the ontological explosion of his sundry personae, a multiplicity of differences, but more originally, even preoriginally, "[a]t the core of Bowie's music is the exhilaration of an experience of nothing and the attempt to hold on to it" (50), an experience of possibility's impending impossibility, a necessarily refracted and partial yet constitutive address with/to/from death. Especially during his final period-though it can be seen in his Nietzschean beginnings, too, as Critchley points out-Bowie's work has the color of a structural mourning, absolutely pervaded by death and nothingness that cannot be wholly known except askance through ghosts, constituted by a finitude that is not only an end but haunts right from the start, an impossibility that is the condition of possibility as such.

If on The Next Day, Bowie "absorbs his past and moves it on, hungry for more," as Lucy Jones' NME review forwards, then on his following and final album, Blackstar, the artistry shifts still further away from retelling history in tangible terms or from reimagining his life's work, and focuses instead on that more, that residuum, which refuses and escapes life's ontological grasp. Being never one to merely repeat himself, Bowie here seems less interested in what simply comes after or what comes next in a career made up of transformations, but alternatively what underlies and persists through those changes; or as Derrida reframes the question in "Eating Well," it is a matter of who comes before the subject, a relational ground that gives rise to so many narratives, regardless whether grand or petit. "The singularity of the 'who' is not the individuality of a thing that would be identical to itself, it is not an atom," says Derrida of this preoriginary instance, but rather "is a singularity that dislocates or divides itself in gathering itself together to answer to the other, whose call somehow precedes its own identification with itself, for to this call I can only answer, have already answered" (100f.).

18 This at bottom underscores how, due to the nonpresent and nonabsent nature of the trace, traditional attempts at autobiography and autodeixis-what Davis describes as "the self-reflexive power of the I" (535)-are doomed to undercut their own project. Like the classical works of mourning, inscriptions of self-reference result eventually in an undecidable irresolution, capable only of conjuring up a ghost when they aim to name a self that nonetheless "is not and cannot be simply present to itself, identical to itself," an "I" that-"though infinitely reproducible, imitable, citable-presents itself as (if) a sign of life," as if but not quite living (541); by "[p]resenting the nonpresence of its supposed antecedent," all that "autobiography gives us is [...] a haunting," all that it provides us is a "figure of understanding that involves the stitching together of disparate traces, which not even the most profound narrative power can pull to a close" (543). It is this fractured and failed logic of autodeixis that Bowie exposes in "Thursday's Child," the opening track of Hours... from the close of the millennium, when he sings that "something about me stood apart [...] breaking my life in two" since birth, a split that betokens a subject "born right out of time," born too early (as Lacan would have it) and yet born late (as Derrida emphasizes), already marked by the trace of finitude, and so belonging to a time out of joint. Motivated, then, by a need to move beyond the impossible confines of autobiography, beyond the spectral limits of autodeixis toward a beyond-the-self with/in the self, what is needed-and what I believe Bowie offers us-is an alternative form of composition attuned not to life's 
presence but to its ghosts, an ethical rhetoric that would respect specters without attempting to render them specular, knowable, grounded and buriable.

In this regard, Ballif argues that because it is always addressed to a missing other, due to the differential and never finished movement of the trace, "writing is the very scene, the very graphic scene of mourning, of the self-life-death-other relation in and through writing." As such, she deploys Derrida's term "auto-bio-thanato-hetero-graphy" in order to rhetorically "describe the constitutive relations between death, the living, the self, the other, and writing-to foreground that all writing is an (impossible) mourning of the self as other and the other as other as a writing of life and/ as death" ("Regarding" 465). Self-life-death-other-writing: this is the same conceptual constellation that informs Blackstar, although I prefer to refer to the album as Bowie's autobituary, his odd-obituary and aud(i)obituary, which not only is less of a mouthful-and so leaves us a little hungrier-but etymological retains a sense of death as passing (Latin ob-eo, "going towards"), an asymptotic approach that is ever nearing but never quite here, in the end remaining an impossible end, for a ghost always survives and passing away never really comes to pass. By stressing death as an interminable process and the condition for the self's emergence-in writing, I am always already declaring myself (dead), always already addressing the (im)possibility of myself-the decomposition implied in an autobituary at the same time recalls what Derrida calls the "spectral asymmetry" that "interrupts" any feelings of invulnerability or autonomy, the unmasterable disproportion that requires a response (Specters 6). Because I will never know my time or place or cause of passing, because Bowie could not predict that he would succumb to his disease mere days after his final gift to the world-as morbidly, ironically, uncannily grand a gesture as it may have appeared-our being's preoriginary structure of mourning enjoins us ineluctably to live towards a death perpetually waiting in the wings, speaking of senseless things. To live with death and mourning in mind is to exist in a way that gives notice to what eternally haunts us, what continually disturbs the singular sense of self, whether as a phantom of the past or a passing to come. Bowie's autobituary, as a form of Wort-zum-Wurm or mot-en-mort that attends to death's interruption of any possible narrative closure, to the impossible-yet-inescapable mourning that structures all signification, therefore stands in stark contrast to conventional biographical or obitual compositions that treat death as fixing life. It is the difference between Elton John's "Candle in the Wind," which has already burnt out long before and so shines no new light on life, and the "solitary candle" that marks the opening and closing verses of "Blackstar," which seemingly continues to flicker forever.

As I have argued thus far, Bowie's output had long been haunted by complicated specters of the non-living and dead other, although neither in the religious sense of death as transitory passing into the next/afterlife nor in mortality as a straightforward biological termination tout court. The finitude and nothingness of death is, rather, formative of and indissociable from growth and change within his work. With his passing approaching as Bowie entered the recording studio for the last time following a terminal cancer diagnosis only a few months after the release of The Next Day, this motif of mourning comes to the fore on Blackstar. The album comes to develop the connection between life and/as death, between subjective (pre)origin and/as end in a sublime fashion beyond the ontological assumptions of conventional moment-to-moment, present-to-present-to-itself narrative. In the album's uncanny lyrics, unconventional musicianship, and macabre imagery, Bowie gives us an image of death-through-life and 
life-through-death that pays heed to his ghosts in a description that avoids decryption, that allows what haunts him to remain spectral without trying to bury it in the sure ground of historicized ontology. By transforming himself into a ghost right before our eyes and ears, by abandoning the closure of autobiography for a disclosure of selfdemise in autobituary, Bowie steps beyond the pretension of a unified, independent self and participates in his own mourning with all of those, fans and family, he will have left behind, those who have made him into a supermassive starman-and so, in their own way, already specters within him. As an autobituary, Blackstar thus suggests a form of composition motivated by, attentive to, and illustrative of a preoriginary structure that undermines the traditional dichotomy between the (living) self and the (dead) other. By aligning himself with the dead and writing from a position of self-impossibility, "Bowie has gone from understanding himself as a performer to understanding himself as," according to Rick Moody, "part of the audience for the performance," so that through his autobituary "Bowie has migrated, through transference, to a new relationship with the audience, in which he understands the audience again, and feels himself to be part of it." Bowie's last work makes mourning a communal ethical experience between the buried and the breathing, a vision of mourning as not only preceding life and death, the self and the other, but exceeding such conceptual limits, allowing for a postfinal address from/with/to the (un)dead.

Perhaps, however, "image" and "vision" are the wrong metaphors to describe this work of self-mourning, which eschews the imaginary self-certainty of specular epistemology for an abocular address with the imperceptible and ambiguous-a position of ethical blindness embodied in the final personality Bowie conceived, the anonymous invalid in the "Lazarus" music video, bedridden with bandages and buttons concealing the singer's famously mutilated eye. Released just three days before the singer died, the clip finds that moribund figure squirming on a hospital-cum-death bed while over slowly sweeping saxes imploring listeners to "look up here, [he's] in heaven" with "scars that can't be seen," which serve as nonabsent remainders of nonpresent ghastly gashes, shadows of a prior violence and traces of death's violence to come. Those saturnine saxophones, by the by, conjure up memories of the performer's early days, prior to his next "Dollar Days," when his half-brother Terry Jones introduced the notquite-Bowie to modern jazz and taught him to play his first instrument, an alto sax. This origin obliquely haunts the artist's final album, the atonal yet lush atmosphere of which is a product of Bowie being backed by an avant-garde jazz quintet in lieu of the typical crunch from a guitar-based band, as on The Next Day. These various unseen scars and faint ghosts function as an invitation to gaze at the imperceptible, for the listener to become at the same time a viewer, seeing what Derrida calls "the furtive and ungraspable visibility of the invisible" (Specters 7), of the specter who haunts between the living and the dead. Accordingly, what Bowie effects in this call to regard his ghost from a position of the listener's own blindness is "a preoriginary injunction," to borrow once more from Ballif, to heed "[ $t]$ he primordial ethical relation: we do not see who looks at us, but we respond to the look" ("Regarding" 464), we cannot help but respond, we are constituted by responding, which is accordingly our ethical response-ability to the (dead) other.

Through this "spectral asymmetry," as Derrida calls it, Bowie "interrupts here all specularity" and "recalls us to anachrony" (Specters 6), declining to fix the deceased in place and in time, refraining from burying himself in the epistemologically clear ground of a metaphysics of (self-) presence, and instead leaving the enigmatic alterity 
of the other-which will be his future self-intact and indefinite. In effect, this is the difference between an autobituary disclosing one's own death and a narrative (auto)biographer or corneal coroner declaring one dead. The latter, says Derrida, "is in fact a matter of a performative that seeks to reassure but first of all to reassure itself by assuring itself, for nothing is less sure, that what one would like to see dead is indeed dead. It speaks in the name of life, it claims to know what that is" (Specters 48), and likewise claims to know what death is and who the dead are, disregarding the absolute alterity that constitutes the other side of our mortality, the inconceivable paradox of possibility's impossibility. In contrast to such ontological certainty, decomposing death and/as life in the mode of autobituary remains attentive to the possibility of impossible specters, the undecidable status of the wholly other, which is never wholly dead, nor wholly singular, but always already plus d'un (Specters 3), one that is one no moreone? no: more-one that is more or less more or less than one, an uncertainty in the final analysis which (constitutes/conditions our) remains. Hence as the song continues in its second verse, this down-and-outright eerie figure of Lazarus not only has "scars that can't be seen," but also "nothing left to lose," in that all that Bowie properly has, has to give (up), is his passing as the possibility of a coming impossibility, an approach to/of nothing, like the empty coffinlike wardrobe, the wooden overcoat without overcoats that bookends the video, reflecting the familiar theme of an echo on either end of life between womb and tomb: "it's nothing to me/it's nothing to see," he intones on "Dollar Days," the album's penultimate track.

Similarly, this morbid motif haunts the album's closing track, where Bowie croaks that he "can't give everything away"-his vocals step by step gliding upwards while the harmony drones almost motionlessly over basic tonic variations (F [I]> Dm7 [vi $\left.{ }^{7}\right]>$ $\mathrm{Bm} 7 b 5\left[\mathrm{vii}^{67} / \mathrm{V}\right]>\mathrm{Bb}$ maj9 $\left[\mathrm{IV}_{9}^{7}\right]$ )-since something spectral always remains, some residual and unknowable trace between everything/more and nothing/less: not only the star's prodigious body of work that survives his body, but something uniquely Bowie's that he is helpless nonetheless to (not) share with others, incapable of wholly loosing from himself. Following a brief recurrence in the song's introduction of the harmonica leitmotif from “A New Career in a New Town" off 1977's Low, we hear the recognizable object-cause (desire's unattainable impetus) that is Bowie's baritone swell intangibly from the rotating vinyl. A voice from the void croons forth hauntingly alive despite its divorce from his breathless body, singing expectantly of "the blackout hearts" and "flowered news" with which his unpassable passing will have been met. Passing away is called unpassable here for two reasons: Firstly, because, as Heidegger puts it, "[n]o one can take the other's dying away from him" (223)-because no one could perish in Bowie's place since, according to "Lazarus," his "drama can't be stolen" or passed to someone else. Yet unpassable also because there is no traversing mortality, no way to get past or cross out the need for finally crossing over, life's finitude being fundamentally no fantasy: "this way or no way," Bowie says of his last days, which are furthermore the condition for living any days at all. Listening to and watching Bowie sing expectantly but without certainty about a passing that will have already come to pass, we become aware once more that, as Mladen Dolar suggests in an echo of Lacan, "the voice without a body is inherently uncanny" (61), in that, together with embodying the ethereal trace between nonpresence and nonabsence, the voice is also the "unique and intimate" product of a particular body while simultaneously recordable, reproducible, response-able even once that body is beneath the earth. 
By performing from a position of subjective deafness and blindness-he will not have lived to watch us watch his video-while enjoining his audience to assume their own nonepistemological yet ethical stance, his uncanny voice calling out from a position of grave nothingness at last, Bowie thus comes to equate his being with his dying, his voice with the void from which it emerges. Thus when, in the first verse of "Lazarus," he proclaims that "everybody knows me now," the line does not declare life's narrative closure or the abrasive pervasiveness of his celebrity, but rather, wrapped in irony, Bowie seems to disclose the essential relation between the self and its limit. Similarly, in the epic title track, he sings of "a solitary candle/in the centre of it all/in the centre of it all/your eyes"-the chiastic doubling in the centre implying an allegorical relation between the sole dimming light source and someone's twin(kling) eyes. Bowie finds himself in the barely distinguishable trace of being between an extinguishing I-shape and multiple I's-the plural splits " $\mathrm{i} / \mathrm{s}$ "-as also between self soulitude and "the prerequisite question of the other" (Davis 540), a tear at the heart of the "I" between wax and wane. It is this void of the self, this blind spot of nonself and alterity at the heart of autodeixis and autobiography, from which Bowie sings presciently, reflexively, in the third person during the bridge, of how "something happened on the day he died/ spirit rose a metre and stepped aside/somebody else took his place, and bravely cried" that the artist is "a blackstar," "not a gangstar"-especially as the former names in astronomical terms a degenerating gravitational object that lacks (a) singularity, a cosmic conception depicted in the accompanying video by a total eclipse, with that image mirrored soon after through a close up of Bowie's distinctive anisocoria. Moreover, the clip enacts this autodeictic di(e)-vision visually as Bowie reiterates the mannerisms of many personae-from the swagger of Ziggy Stardust to Major Tom, the astronaut's suit at the video's start now empty of all but a swagged out skull-adding to his gallery the eyeless figure with the shock of gray hair who returns, who is repeated, in the "Lazarus" video.

Moreover, this interplay between the specular and the specter, between the eye(less) and the loss of self (leading to the other), the epistemologically grounded and the ethically uncertain, finds its way as well into the packaging of Blackstar. Among a range of other formats, the record was released in limited edition as a translucent vinyl-the (non)color common to all pressings prior to their artificial blackening-with a wholly/ holey black label in the center of it all, giving the album the clear appearance of an eye. Designed in this way, such a vision of what makes vision possible as such seems almost to be a realization of Derrida's "spectral asymmetry" or the "visor effect" wherein "we do not see who looks at us" (Specters 7), and is evident even before removing the record from its sleeve, since the all black album cover itself is marked by a large cutout section in the shape of a star. That funereal blackness is only an illusion, however, and in fact becomes illuminated by a glowing galaxy of stars when the album is held up to sunlight, yet another gift from beyond the grave. Performing the logic of the nonpresent and nonabsent trace that structures all signification, Bowie here as elsewhere, as everywhere throughout his work, as in the title of his museum retrospective, figures himself a gravitational void or a nonsingular antistar, "not a wandering star" but "a star's star" revealed through différance. In his final work Bowie positions himself as an icon sous rature, disclosing the rapture of a fatal nothingness at his core, a beyond-life constituting the heart of life, and a ghostliness that conditions the possibility of any signification: these are the specters from mourning that allow him to continually converse in verses with us despite/due to his death. 
"How then to retheorize rhetorical practices while acknowledging the address, the addressor, and the addressee as being essentially haunted?" Ballif asks in her essay on hauntological composition ("Regarding" 466, emphasis in the original), and the specter of David Bowie responds, pace his passing, through the mournful work of autobituary in his final period, offering one avenue for imagining the inexorable interplay between life and/as death, the self and/as other, more and/as less. On Blackstar and, to a lesser extent, on The Next Day, Bowie illuminates a form of artistry-whether with sound, with images, or with words-that fearlessly inhabits a haunted space and attunes itself to the ghostly traces that inform it; furthermore, this rhetorical autobituary, as a writingtowards-death, is the culmination of the performer's strange fascination with finitude and loss, with nothingness and mortality. Already on 1971's Hunky Dory, arguably the young artist's most overtly autobiographical album, Bowie sang that "knowledge comes with death's release." Through the work of his final period, following the last of so many aesthetic resurrections-Bowie was always already Lazarus in legion-we are left with the suggestion that such knowledge is neither of the self nor of the epistemologically privileged present. Rather, with death comes a nonrational apparitional knowledge of those uncanny ghosts that remain otherwise buried, the nonpresent and nonabsent traces that refuse apprehension except when cast in the oblique light of an eclipse, the spectral shadow of a blackstar.

\section{BIBLIOGRAPHY}

Abraham, Nicolas, and Maria Torok. "Mourning or Melancholia: Introjection versus Incorporation." In The Shell and the Kernel: Renewals of Psychoanalysis. vol. 1. Trans. Nicholas T. Rand. Chicago: University of Chicago Press, 1994. 125-138.

Ballif, Michelle. “Regarding the Dead." Philosophy \& Rhetoric 47 :4 (2014): 455-471.

---. Theorizing Histories of Rhetoric. Carbondale: Southern Illinois University Press, 2013.

Critchley, Simon. Bowie. New York: OR Books, 2014.

Davis, Diane. "Autozoography : Notes Toward a Rhetoricity of the Living." Philosophy \& Rhetoric $47: 4$ (2014): 533-553.

Derrida, Jacques. “'Eating Well,' or the Calculation of the Subject: An Interview with Jacques Derrida." In Who Comes After the Subject. Ed. Eduardo Cadava, Peter Connor, and Jean-Luc Nancy. London: Routledge, 1991. 96-119.

---. "Fors : The Anglish Words of Nicolas Abraham and Maria Torok." In The Wolf Man's Magic Word. Trans. Barbara Johnson. Minneapolis: University of Minnesota Press, 1986. xi-xlviii.

---. Limited Inc. Trans. Samuel Weber and Jeffrey Mehlman. Evanston, IL: Northwestern University Press, 1988.

---. Margins of Philosophy. Trans. Alan Bass. Chicago: University of Chicago Press, 1984. 
---. Specters of Marx: The State of the Debt, the Work of Mourning and the New International. Trans.

Peggy Kamuf. New York: Routledge, 1994.

---. The Beast and the Sovereign. vol. 2. Trans. Geoffrey Bennington. Chicago: University of Chicago

Press, 2011.

Dolar, Mladen. A Voice and Nothing More. Cambridge, MA: MIT Press, 2006.

Freud, Sigmund. "Mourning and Melancholia." In The Standard Edition of the Complete Psychological Works of Sigmund Freud, Volume XIV (1914-1916): On the History of the Psycho-Analytic

Movement, Papers on Metapsychology and Other Works. Trans. James Strachey. London: Vintage, 2001. 243-258.

Heidegger, Martin. Being and Time: A Translation of Sein Und Zeit. Trans. Joan Stambaugh. Albany, NY: State University of New York Press, 1996.

Kirby, Joan. “'Remembrance of the Future': Derrida on Mourning.” Social Semiotics 16 :3 (2006): 461-472.

Klein, Melanie. "Mourning and Its Relation to Manic-Depressive States." The International Journal of Psycho-Analysis $21: 2$ (1940): 125-153.

Lacan, Jacques. The Ego in Freud's Theory and in the Technique of Psychoanalysis, 1954-1955. vol. 2. Ed. Jacques-Alain Miller. Trans. Sylvana Tomaselli. New York: W. W. Norton \& Company, 1991.

Murray, Martin. "Ch-Ch-Ch-Ch-Changes: David Bowie Is and the Stream of Warm Impermanence." Postmodern Culture 23.2 (2013): n. pag.

\section{ABSTRACTS}

This article addresses the uncanny fascination for specters that long haunted David Bowie's artistry. Following the hauntological work of Jacques Derrida and a few of his followers, I consider the ways in which the late Bowie came to haunt the late Bowie, how mortality and mourning condition his final output, especially on Blackstar, his last album. In tracing these ghostly traces, I show how his music and videography pursue an alternative form of composition beyond the conventional attempts toward narrative closure of autobiography, a form of spectral rhetoric that I outline as autobituary. Through practices of writing attuned to the mournful structure that conditions signification, Bowie responds to Derrida's and Michelle Ballif's call to find ways of ethically addressing the (dead) other's absolute alterity. In the form of autobituary, I suggest that Bowie provides one avenue for reconceiving the conventional relation between life and death, self and other, addressor and addressee.

Cet article traite de l'intérêt étrange pour les spectres qui ont caractérisé l'art artistique de David Bowie. À la suite du travail hantologique de Jacques Derrida et de quelques-uns de ses disciples, je considère les façons dont le défunt Bowie hante le dernier Bowie, et je considère les façons dont la mortalité et le deuil qui déterminent sa musique finale, en particulier sur Blackstar, son dernier album. En esquissant ces traces fantomatiques, je montre les façons dont sa musique et sa vidéographie poursuivent une forme de composition différente de la fermeture narrative classique de l'autobiographie, une forme de rhétorique spectrale que je décris en autobituary. Au moyen de pratiques d'écriture réceptives à la structure hantée qui détermine la signification, Bowie répond à l'appel de Derrida et Michelle Ballif pour trouver des moyens d'aborder éthiquement l'altérité absolue de l'autre spectral. Sous la forme d'une note autobituary, je suggère que Bowie fournit une méthode pour reconcevoir la relation conventionnelle entre la vie et la mort, soi et autre, l'adresse et le destinataire. 
INDEX

Mots-clés: autobiographie, hantologie, rhétorique, deuil, signification

Keywords: autobiography, hauntology, rhetoric, mourning, address

\section{AUTHORS}

\section{JAKE COWAN}

Doctoral candidate

Department of English

University of Texas at Austin

jake.cowan@utexas.edu 